\title{
微生物高种学术讨论 会
}

由中国微生物学会和中国科学院微生 物研究所主办的微生物育种学术讨论会, 于 1973 年 5 月 7 日至 16 日在安徽省芜湖市召 开. 参加会议的有来自全国 22 个省、市、自 治区的 84 个生产部门、科研部门和教学部门 的 150 多名代表. 会议贯彻了“百花齐放、百 家争鸣”的方针和“理论联系实际”的原则, 检 阅和交流了成绩和经验, 讨论了当前存在的 一些问题,交换了进一步开展工作的意见.

会议通过许多单位的工作报告和一些同 志所作的国际动态介绍, 结合各单位自己的 工作进行了讨论. 从会议交流报告中, 也看 到了代谢控制等理论和杂交育种等技术在微 生物育种工作中已经有了初步应用. 另外一 些报告也表明, 当前国内微生物育种工作中, 已经开始注意到诱变规律的掌握和篮选方法 的改进, 从而较快地提高了工作效率.

通过交流和讨论, 对一些问题的认识也 提高了. 代表们认为, 整个微生物菌种的选 育工作, 都关系到节粮代粮的问题. 农用抗 菌素菌种的选育, 对于支援农业生产更有直 接意义. 因此, 进一步认识到微生物育种工 作对于贯彻毛主席关于“备战、备荒、为人民” 和 “深挖洞, 广积粮, 不称霸” 的指示的重要 位, 从而鼓舞了干劲, 增强了搞好工作的信 心。

会议讨论了前进过程中存在的一些问 题. 例如当前微生物育种工作远远不能满足 生产实践提出的要求; 在育种方法上结合篮 选方法、工艺条件考虑不够; 与国外先进水平 比较差距较大; 国内绝大部分都是诱变育种, 杂交育种用于生产的很少. 其它如代谢控制 理论的应用也是刚刚开始, 基本理论的研究
如诱变机制等尚未很好开展。有些新技术、 新方法尚未很好建立, 影响了育种工作水平 的迅速提高; 此外,生产、科研和教学单位之 间的互相配合协作还不够密切, 从事不同学 科的研究人员在基本理论研究方面密切配合 和互相渗透还不够. 但是, 当前总的形势是 一片大好, 代表们一致认为, 这些前进过程中 存在的问题,通过努力一定能得到解决.

会议讨论了对今后进一步开展工作的意 见, 认为首先必须认真总结诱变育种经验, 找 出诱变育种工作的规律. 为此, 应普及诱变 育种的基本知识, 对蓬勃开展的诱变育种群 众运动经验, 进行自下而上的总结, 以便找出 规律, 减少盲目性. 在此基础上进一步开展 诱变机制包括修复机制的研究, 以不断提高 育种的科学技术水平.

会议认为, 必须应用代谢控制的理论, 加 速育种工作的进展. 从国内外微生物育种工 作的动态来说, 微生物育种工作的技术路线, 已从直接根据产量进行选育发展到从代谢产 物的合成途径和控制调节机制的角度着手考 虑育种方法的阶段. 这种趋势值得我们在今 后育种工作中予以深切注意.

会议认为, 今后必须采用先进的遗传和 生物化学技术来改进育种手段. 由于诱变育 种的盲目性比较大, 要获得一个具有多种优 良性状的菌种、还必须采用杂交、转化、转导 等手段来达到优良性状的合理组合和单个基 因或基因组数量的增加, 从而改变微生物的 遗传结构, 达到定向育种的目的. 此外, 还必 须采用先进的生物化学技术来加速代谢调节 控制机制的研究.

[中国科学院微生物研究所供稿] 